Article

\title{
Religion and Ethical Attitudes toward Accepting a Bribe: A Comparative Study
}

\section{Robert W. McGee ${ }^{1}$, Serkan Benk ${ }^{2, *}$ and Bahadır Yüzbaşı ${ }^{2}$}

1 School of Business and Economics, Fayetteville State University, 1200 Murchison Road Fayetteville, NC 28301, USA; E-Mail: rmcgee3@uncfsu.edu

2 Faculty of Economics and Administrative Sciences, Inonu University, 44280 Malatya, Turkey; E-Mail: bahadir.yuzbasi@inonu.edu.tr

* Author to whom correspondence should be addressed; E-Mail: serkan.benk@inonu.edu.tr; Tel.: +90-422-377-4260; Fax: +90-422-341-0438.

Academic Editor: Klaus Baumann

Received: 20 July 2015 / Accepted: 23 September 2015 / Published: 29 September 2015

\begin{abstract}
This study presents the results of an empirical study of ethical attitudes toward bribe taking in six religions - Christianity, Islam, Buddhism, the Baha'i faith, Hinduism, and Judaism. The paper begins with a discussion of the theoretical and empirical literature on the subject. The empirical part of the study examines attitudes toward accepting bribes in 57 countries from the perspectives of six religions using the data from Wave 6 (2010-2014) of the World Values Survey. The sample population is more than 52,000. More than a dozen demographic variables were examined. The study found that attitude toward bribe taking does differ by religion.
\end{abstract}

Keywords: bribery; ethics; religion; empirical studies; World Values Survey; demographic; logistic regression

\section{Introduction}

This paper examines the question of whether it is acceptable to take a bribe. It is an empirical study that used the most recent data from the World Values Surveys (Wave 6), which were collected in 57 countries between 2010 and 2014. The sample size was more than 52,000, and was broken down by 
religion. Six religions had sufficiently large sample sizes to be included in the study-Christian, Muslim, Hindu, Baha'i, Buddhist and Jew.

More than a dozen demographic variables, such as age, gender, education level, etc., were examined to determine whether any of these variables made a difference. The survey found that the attitude toward bribery does differ by religion, and that certain demographic variables had significantly different attitudes toward the ethics of taking a bribe. However, the results of the examination of the various demographic variables sometimes differed by religion. For example, the gender differences were significant for Christians and Muslims, but not for the other four religions.

Some other studies have been conducted examining the ethics of bribery. This theoretical and empirical literature is reviewed. The results of the present study are presented in Section four. Areas for future research are identified and discussed in the conclusion section.

\section{Literature Review}

If one examines bribery from the perspective of economic efficiency, a case can be made that bribery is, in at least some cases, an ethical practice. Johnsen [1] suggests that in cases where bribery reduces transaction costs, thereby increasing efficiency, there is potential benefit to consumers. He suggests that in the Honda commercial bribery case, the Honda dealer network may have actually benefited. He suggests that the term "commercial bribery" not be used until an analysis finds that the relevant community is likely to have been harmed. He would substitute a more neutral term - third-party payments - until such time as harm has been found, since it is a more neutral term.

However, not all grease payments increase efficiency. A study by Kaufmann and Wei [2] found that firms that pay more in bribes also spend more time negotiating with bureaucrats, and that they face a higher rather than lower cost of capital. Part of the problem inherent in applying ethical theory to any question is the determination of which set of ethical principles to apply. Utilitarianism is by far the most popular ethical system among economists and perhaps among policy makers as well [3]. But it is not the only ethical system. In fact, some ethicists think that it is not the best system. There are several reasons for this belief, not the least of which is because a pure utilitarian system totally ignores rights [4,5]. Some other ethical systems look at rights as one of the chief pillars of the system. Kantian ethics also looks to duties [6]. Virtue ethics, which is Aristotelian-based, looks to see whether a policy or act results in human flourishing [7]. Baron, Pettit and Slote have debated the pros and cons of utilitarianism, Kantianism and virtue ethics and have uncovered some interesting insights [8]. Graham slices the ethical pie into eight parts by identifying additional ethical approaches [9].

The point is that looking at an ethical issue from different perspectives can lead to different results. What may be viewed as ethical by applying one set of principles may be unethical if another set of ethical principles are applied. It is what makes life interesting. It is possible to go beyond the superficial conclusion that anything corrupt is also unethical by applying ethical principles. Wong and Beckman have done that in their study of corruption and bribery [10]. They developed a model to make ethical decisions that applies both utilitarian and Kantian principles to a range of ethical issues business people encounter. They correctly point out that utilitarian ethics is basically a cost-benefit analysis. If the gains exceed the losses, the policy or act is ethical. 
One problem with this approach is that some affected groups might be left out of the utilitarian calculus. The classic utilitarian position asserts that an act or policy is ethical if the result is the greatest good for the greatest number. That position implies that all affected groups must be included, not just the company the manager works for. For example, if General Motors made a car that explodes upon impact, the decision might be made to continue making the car if the losses from lawsuits are less than the gains to be made by continuing to sell the car. The losses to those who are blown up by driving the GM car are left out of the equation.

If one adds duties to the equation, the conclusion may be different. For example, if one begins with the premise that there is a duty not to sell cars that explode on impact, the conclusion would be to take the exploding cars off the market, even if the result would be a positive-sum game for the auto manufacturer. Applying virtue ethics might lead to the same result. If it is concluded that human flourishing results when auto makers do not sell cars that explode on impact, the ethical thing to do would be to not sell cars that explode on impact. Shaw does not believe that a utilitarian approach is very useful in determining whether bribes are ethical because utilitarianism is situation specific. Benefits and costs may not be easy to determine [11].

Does bribery result in human flourishing? Do the pros of bribery outweigh the cons? One must not jump to conclusions before doing a thorough ethical analysis, using whatever ethical tools one thinks are most appropriate in the circumstances. Let us take the case of the relationship between bribery and foreign direct investment (FDI). There are many good things to be said about FDI. The more of it one has, the higher the economic growth rate and standard of living. Humans flourish where there is a large amount of FDI. Other good things also happen to the internal structure of countries that have a large amount of FDI. Political freedom tends to increase, for example [12].

One might assume that the relationship between bribery and FDI is inverse. In other words, the more bribery there is in a society, the less FDI there is. While that may be the case sometimes $[13,14]$, it is not always the case [15]. Egger and Winner did a study involving 73 developed and less developed countries examining this issue [12]. They found that the relationship was positive rather than negative. FDI actually increased with corruption. They concluded that corruption stimulated FDI. They point out that whether bribery has a positive or negative effect depends on whether bribery is seen as a "grabbing hand" or a "helping hand." If the bribe taker is merely extracting payment without any corresponding benefit that would not otherwise be provided, it is parasitical. In such cases, business people are more hesitant to do business in such an environment because it increases the cost of business without any corresponding benefit.

However, the grabbing hand cases are not the only cases. If a foreign investor is being inundated with red tape and inefficiency and someone offers to show them a way around the system in exchange for a grease payment, the bribe taker is actually performing a valuable service, and is perhaps also reducing the cost of doing business. In such cases, it is a helping hand rather than a grabbing hand. Ethicists might conclude that in such cases neither party to the transaction is acting improperly. Sanyal and Samanta examined the relationship between bribe taking and real gross domestic product (GDP) [16]. They found that bribery generally has an adverse effect on the rate of economic growth. However, the relationship between these two variables varied considerably in individual countries, which indicates that some country-specific factors have an effect on both bribery and the rate of economic growth. 
Premeaux and Mondy conducted a study linking management behavior to ethical philosophy and concluded that managers tend to be utilitarians [17]. Premeaux replicated this study a decade later and found that the emphasis had shifted somewhat [18]. While managers continued to be basically utilitarian, they were starting to place more emphasis on duty, perhaps out of fear of lawsuits or perhaps because of the belief that they should do the right thing regardless of personal benefit. The two studies also examined a number of demographic variables to determine whether demography made a difference in attitude. They found that it did not, as a general rule. There were no significant variations by gender, race, marital status, region, income, religion, political affiliation, education or type or size of firm. However, those who were five years or less away from retirement were more likely to apply rules or rights theory. The authors attributed this difference in outlook either to extensive business experience or because of the belief that the short-term gains would not outweigh the long-term effects of the decision.

Some other studies have also examined demographic variables in connection with bribery. Swamy et al. examined the relationship between gender and corruption and found that women are less involved in bribery and are less likely to condone bribery [19]. Their examination of cross-country data also found that there is less corruption in countries where women hold a larger share of parliamentary seats and more senior positions in the governmental bureaucracy, and where they comprise a larger percentage of the labor force.

A number of other studies have examined bribery, often in conjunction with other forms of corruption. Roy and Singer examined bribery and other forms of corruption in India and suggest some methods or techniques for reducing it [20]. Atanasov concluded that conflict resolution, which involves the process of reaching a mutually beneficial solution for the parties undertaking negotiations, may not be a socially optimal solution [21]. He argues that bribery may play a moral role in the process. A number of organizations and parties have come out in favor of doing something to reduce the amount of corruption in general and bribery in particular that takes place in international business. The OECD Convention on Combating Bribery of Foreign Public Officials is one such document [22]. The question of how effective this document has been is subject to discussion [23,24].

Sanchez, Gomez and Wated examined managerial tolerance of bribery in Latin America [25]. They concluded that regionally dominant cultural values help shape Latin American managers' attitudes, which exacerbate their tolerance level. Their attitudes regarding collectivism and power distance have a role to play in their attitudes. Bernardi, Witek and Melton examined ethical attitudes of students in Colombia, Ecuador, South Africa and the United States and found that the U.S. sample held views that were less ethical in three out of four of the cases being examined [26].

\section{Methodology}

\subsection{The Data}

For the purpose of this paper, data were derived from the most recent wave of the World Values Surveys (WVS), conducted in the period of 2010-2014. The survey was administered to facilitate cross-national and religious comparison of basic values in a wide range of concerns and carried out through face-to-face interviews. The wording of the questions, answers, and sequencing were identical 
in all local languages. The last version of the survey is referred to as Wave 6, which collected data from 57 countries with more than 85,000 respondents [27]. This study was focused on only six different religions: Christianity, Islam, Buddhism, the Baha'i faith, Hinduism, and Judaism. This resulted in a substantial reduction of the sample size to 52,251 observations. Both dependent and independent variables for the analysis were constructed based on the relevant WVS questions.

\subsection{The Dependent Variable}

In this study, one dependent variable was examined. The dependent variable of attitudes toward accepting bribery was measured by the item "Someone accepting a bribe in the course of their duties". A 10-point Likert Scale was used, where $1=$ never justifiable and $10=$ always justifiable. For logistic regression analysis the 10-point scale responses converted into dichotomous variables with 1 being "never justifiable" and 0 otherwise. This seemed more appropriate. Because, the distributions of the answers of dependent variable show that more than half the sample clearly stated that accepting a bribe was never justified (except Baha'i), while the others are scattered over the rest of the categories. A limitation was that the one dependent variable was used in terms of a single item of a global attitude towards accepting bribery. Although the single global item has its limitation in gauging attitudes toward accepting bribes, it was reported to be fairly stable over time, and they were also highly correlated with more specific attitudes [28,29].

\subsection{The Independent Variables}

In order to determine how religions affect ethical attitudes toward taking a bribe, there are several variables included as control variables in the analysis. These variables, accordingly, were classified into four groups: socioeconomic variables, social bond variables, attitudinal variables, and religiosity variables.

Socioeconomic variables: Six socioeconomic variables were included in the analysis. Age was measured as a respondent's reported age in the year of the survey. Gender was a binary variable where male $=0$ and female $=1$. Education level was assessed with the available data in the survey as an ordinal variable, where No formal education $=1$ and University-level education with a degree $=9$. Social class was assessed with a single item (reverse coded): "People sometimes describe themselves as belonging to one of the range of responses used to lower class $=1$ to upper class $=5$." Literate situation was a binary variable where illiterate $=0$ and literate $=1$. Scale of income was assessed with subjective judgment about the respondent's own relative standing where lowest group $=1$ and highest group for the socioeconomic status $=10$.

Social bond variables: Three social bond variables were included in the analysis. Marriage was a dummy variable where married, living together as married, and widowed $=1$; all other non-marital statuses $=0$. Employment status was measured as a dichotomized variable where paid employment, retired/pensioned, housewife, and student $=1$; unemployed $=0$. Sector of employment was measured as a dichotomized variable where government or public institution $=1$ and private business or industry, private non-profit organization, and other (autonomous/informal) sector $=0$.

Attitudinal variables: Five attitudinal variables were included in the analysis. Happiness was assessed with a single item (reverse coded): "Taking all things considered, would you say you are not 
at all happy $=1$, not very happy $=2$, quite happy $=3$ and very happy $=4$ ". Political scale was measured by the item: "In political matters, people talk of 'the left' and 'the right.' How would you place your views on this scale, generally speaking?" The range of responses used a 10-point Likert Scale where Left $=1$ and Right $=10$. Government responsibility was assessed with by item: "How would you place your views on this scale? The range of responses used a 10-point Likert Scale where "Government should take more responsibility to ensure that everyone is provided for $=1$ and people should take more responsibility to provide for themselves $=10$." Importance of democracy was measured with a single item: "How important is it for you to live in a country that is governed democratically? The range of responses used a 10-point Likert Scale where not at all important $=1$ and absolutely important $=10$." Confidence in government was assessed with a single item (reverse coded): "How much confidence do you have in government? Not at all = 1, Not very much $=2$, Quite a lot $=3$, and a great deal $=4$."

Religiosity variables: Five religiosity variables were included in the analysis. Attendance at religious services was measured by item (reverse coded): “Apart from weddings and funerals, about how often do you attend religious services these days? Never, practically never $=1$, less often $=2$, once a year $=3$, only on special holy days $=4$, once a month $=5$, once a week $=6$, and more than once a week $=7$. Religious person was measured as a dichotomized item: "Independently of whether you attend religious services or not, would you say you are: A religious person $=1$ and not a religious person and an atheist $=0$. Belief in God was assessed with a binary item: Yes $=1$ and No $=0$. God Importance was measured by the item: "How important is God in your life? The range of responses used a 10-point Likert Scale where Not at all important $=1$ to very important $=10$." Praying was assessed with the item (reverse coded): "Apart from weddings and funerals, about how often do you pray? Never, practically never $=1$, Less often $=2$, once a year $=3$, only on special holy days $=4$, only when attending religious services $=5$, several times each week $=6$, Once a day $=7$ and several times a day $=8 . "$

\section{Results}

Table 1 reported the results of the descriptive analyses of all the variables in this study. The Christian sample consists of Anglican $(N=1763)$, Armenian Apostolic Church $(N=1212)$, Assembly of God $(N=1704)$, Baptist $(N=421)$, Evangelical $(N=831)$, Jehovah witnesses $(N=54)$, Orthodox $(N=7140)$, Pentecostal $(N=79)$, Presbyterian $(N=111)$, Protestant $(N=5016)$, Roman Catholic $(N=12527)$, The Church of Sweden $(N=689)$, Dutch Reformed $(N=126)$, and Reformed Churches in the Netherlands $(N=75)$. The Muslim sample consists of Shia $(N=51)$, Sunni $(N=3185)$ and Muslim $(N=13879)$. The other religions are Buddhist $(N=2026)$, Baha'i $(N=583)$, Hindu $(N=4040)$ and Jew $(N=375)$.

The mean score for justifiability of accepting a bribe was 0.75 in Muslim, 0.74 in Buddhist, 0.72 in Hindu, 0.71 in Jew, 0.69 in Christian, and 0.40 in Baha'i, respectively, where "never justifiable" $=1$ and "justifiable" $=0$. Thus, it appears that, overall, Muslims were most opposed to accepting a bribe and Baha'is were least opposed. 
Table 1. Descriptive statistics of the sample by religions $(N=52,251)$.

\begin{tabular}{|c|c|c|c|c|c|c|c|c|c|c|c|c|c|c|c|c|c|c|}
\hline \multirow{2}{*}{ Variables } & \multicolumn{3}{|c|}{ Christian $(N=31,748)$} & \multicolumn{3}{|c|}{ Muslim $(N=17,115)$} & \multicolumn{3}{|c|}{ Buddhist $(N=2026)$} & \multicolumn{3}{|c|}{ Baha'i $(N=\mathbf{5 8 3})$} & \multicolumn{3}{|c|}{ Hindu $(N=404)$} & \multicolumn{3}{|c|}{ Jew $(N=375)$} \\
\hline & Range & Mean & SD & Range & Mean & SD & Range & Mean & SD & Range & Mean & SD & Range & Mean & SD & Range & Mean & SD \\
\hline \multicolumn{19}{|c|}{ Dependent Variable } \\
\hline Accepting bribery & $0-1$ & 0.69 & 0.464 & $0-1$ & 0.75 & 0.434 & $0-1$ & 0.74 & 0.437 & $0-1$ & 0.40 & 0.490 & $0-1$ & 0.72 & 0.448 & $0-1$ & 0.71 & 0.454 \\
\hline Otherwise & $9864(31.1 \%)$ & & & $4239(24.8 \%)$ & & & $496(24.5 \%)$ & & & $348(59.7 \%)$ & & & $109(27 \%)$ & & & $105(28 \%)$ & & \\
\hline Never justifiable & $21,521(67.8 \%)$ & & & $12,627(73.8 \%)$ & & & $1437(70.9 \%)$ & & & $232(39.8 \%)$ & & & $286(70.8 \%)$ & & & $257(68.5 \%)$ & & \\
\hline Don't know and no answer & $363(1.1 \%)$ & & & $249(1.4 \%)$ & & & $93(4.6 \%)$ & & & $3(0.5 \%)$ & & & $9(2.2 \%)$ & & & $13(3.5 \%)$ & & \\
\hline \multicolumn{19}{|c|}{ Socioeconomic variables } \\
\hline Age & & 44.29 & 17.531 & & 37.57 & 14.176 & & 50.42 & 16.675 & & 35.19 & 14.285 & & 44.70 & 16.239 & & 44.14 & 17.611 \\
\hline Gender (Femal & $=1)$ & 0.56 & 0.496 & & 0.51 & 0.499 & & 0.52 & 0.499 & & 0.59 & 0.490 & & 0.56 & 0.497 & & 0.50 & 0.500 \\
\hline Education Le & & 5.81 & 2.253 & & 5.27 & 2.614 & & 6.23 & 2.190 & & 5.95 & 1.757 & & 5.01 & 2.190 & & 7.00 & 2.326 \\
\hline Social Clas & & 2.70 & 0.973 & & 2.79 & 1.005 & & 2.70 & 0.873 & & 2.05 & 1.051 & & 2.64 & 0.959 & & 2.96 & 0.936 \\
\hline Literate Situation (L & terate $=1)$ & 0.96 & 0.195 & & 0.86 & 0.350 & & 0.98 & 0.130 & & 0.86 & 0.347 & & 0.94 & 0.243 & & 0.94 & 0.230 \\
\hline Scale of Inco & & 4.77 & 2.039 & & 5.17 & 2.095 & & 4.64 & 2.336 & & 5.26 & 2.079 & & 5.12 & 1.971 & & 5.38 & 1.963 \\
\hline \multicolumn{19}{|c|}{ Social bond variables } \\
\hline Marital Status (Ma & ried = 1) & 0.70 & 0.458 & & 0.70 & 0.460 & & 0.79 & 0.406 & & 0.48 & 0.500 & & 0.73 & 0.446 & & 0.68 & 0.466 \\
\hline Employment (Empl & oyed = 1) & 0.91 & 0.282 & & 0.92 & 0.278 & & 0.96 & 0.192 & & 0.63 & 0.482 & & 0.93 & 0.247 & & 0.95 & 0.211 \\
\hline Sector of Employment (C & overnment =1) & 0.31 & 0.461 & & 0.33 & 0.471 & & 0.14 & 0.352 & & 0.11 & 0.312 & & 0.23 & 0.424 & & 0.22 & 0.414 \\
\hline \multicolumn{19}{|c|}{ Attitudinal variables } \\
\hline Happiness & & 3.17 & 0.723 & & 3.18 & 0.745 & & 3.20 & 0.638 & & 3.10 & 0.850 & & 3.39 & 0.720 & & 3.19 & 0.591 \\
\hline Political Sca & & 5.70 & 2.299 & & 6.22 & 2.337 & & 5.63 & 2.010 & & 6.54 & 1.966 & & 6.51 & 2.392 & & 5.14 & 2.176 \\
\hline Government Respc & nsibility & 4.54 & 2.910 & & 4.37 & 3.033 & & 4.47 & 2.660 & & 5.83 & 2.663 & & 6.04 & 2.859 & & 5.43 & 2.754 \\
\hline Importance of Der & hocracy & 8.37 & 2.036 & & 8.27 & 2.133 & & 8.53 & 1.795 & & 7.84 & 2.033 & & 8.51 & 2.073 & & 8.80 & 1.695 \\
\hline Confidence in Gov & ernment & 2.35 & 0.914 & & 2.53 & 1.062 & & 2.47 & 0.812 & & 2.60 & 0.936 & & 2.75 & 0.865 & & 2.41 & 0.793 \\
\hline \multicolumn{19}{|c|}{ Religiosity variables } \\
\hline Attendance at Religio & us Services & 4.42 & 1.950 & & 4.05 & 2.287 & & 3.59 & 1.584 & & 5.58 & 1.574 & & 4.27 & 1.876 & & 3.21 & 1.801 \\
\hline Religious person (Religio & ity Person = 1) & 0.78 & 0.412 & & 0.76 & 0.424 & & 0.48 & 0.500 & & 0.89 & 0.309 & & 0.80 & 0.400 & & 0.48 & 0.500 \\
\hline Believe in God (Y & $\mathrm{es}=1)$ & 0.93 & 0.263 & & 0.99 & 0.097 & & 0.78 & 0.416 & & 0.97 & 0.173 & & 0.98 & 0.148 & & 0.88 & 0.322 \\
\hline God importar & & 8.03 & 2.566 & & 9.25 & 1.626 & & 6.28 & 2.526 & & 8.28 & 2.125 & & 9.00 & 1.921 & & 6.46 & 2.685 \\
\hline
\end{tabular}


Model fitting via logistic regression is sensitive to the collinearity among the independent variables [30]. Tolerance (TOL) and variance inflation factor (VIF) are two important indexes for the multi-collinearity diagnosis. A TOL value smaller than 0.2 is an indicator of Multicollinearity between independent variables and a TOL value smaller than 0.1 suggests serious Multicollinearity [31]. In this study, both indexes were calculated (Table 2), and variables with VIF $>2$ and TOL $<0.4$ were excluded from the logistic analysis [32]. After the multi-collinearity analysis and the exclusion of highly correlated independent variables, such as Age, Attendance at Religious Services, God importance and praying, the sample datasets were then used to input to the logistic regression algorithm within the Statistical Package for Social Science (SPSS).

Table 2. The multicollinearity diagnosis indexes for independent variables.

\begin{tabular}{|c|c|c|c|c|c|c|c|c|c|c|c|c|}
\hline \multirow[b]{2}{*}{ Independent variables } & \multicolumn{2}{|c|}{ Christian } & \multicolumn{2}{|c|}{ Muslim } & \multicolumn{2}{|c|}{ Hindu } & \multicolumn{2}{|c|}{ Baha'i } & \multicolumn{2}{|c|}{ Buddhist } & \multicolumn{2}{|c|}{ Jew } \\
\hline & TOL & VIF & TOL & VIF & TOL & VIF & TOL & VIF & TOL & VIF & TOL & VIF \\
\hline \multicolumn{13}{|c|}{ Socioeconomic variables } \\
\hline Age & 0.766 & 1.305 & 0.768 & 1.302 & 0.498 & $2.007 *$ & 0.508 & 1.970 & 0.584 & 1.713 & 0.540 & 1.853 \\
\hline Gender & 0.968 & 1.033 & 0.945 & 1.058 & 0.793 & 1.261 & 0.880 & 1.137 & 0.945 & 1.058 & 0.788 & 1.269 \\
\hline Education level & 0.734 & 1.362 & 0.645 & 1.550 & 0.509 & 1.963 & 0.641 & 1.560 & 0.751 & 1.332 & 0.600 & 1.666 \\
\hline Social class & 0.746 & 1.341 & 0.756 & 1.323 & 0.722 & 1.386 & 0.661 & 1.514 & 0.746 & 1.341 & 0.726 & 1.377 \\
\hline Literate situation & 0.901 & 1.110 & 0.777 & 1.287 & 0.712 & 1.404 & 0.721 & 1.388 & 0.916 & 1.092 & 0.781 & 1.280 \\
\hline Scale of income & 0.764 & 1.308 & 0.823 & 1.215 & 0.640 & 1.563 & 0.688 & 1.453 & 0.675 & 1.481 & 0.625 & 1.599 \\
\hline \multicolumn{13}{|c|}{ Social bond variables } \\
\hline Marital status & 0.858 & 1.165 & 0.796 & 1.256 & 0.661 & 1.514 & 0.585 & 1.708 & 0.719 & 1.391 & 0.639 & 1.565 \\
\hline Employment & 0.959 & 1.043 & 0.978 & 1.022 & 0.806 & 1.241 & 0.760 & 1.316 & 0.926 & 1.080 & 0.762 & 1.312 \\
\hline Sector of employment & 0.864 & 1.158 & 0.870 & 1.149 & 0.765 & 1.307 & 0.880 & 1.137 & 0.928 & 1.078 & 0.816 & 1.226 \\
\hline \multicolumn{13}{|c|}{ Attitudinal variables } \\
\hline Happiness & 0.910 & 1.099 & 0.943 & 1.060 & 0.718 & 1.393 & 0.858 & 1.166 & 0.894 & 1.119 & 0.751 & 1.332 \\
\hline Political scale & 0.951 & 1.052 & 0.945 & 1.058 & 0.641 & 1.560 & 0.904 & 1.106 & 0.892 & 1.121 & 0.862 & 1.161 \\
\hline Government responsibility & 0.949 & 1.054 & 0.952 & 1.050 & 0.767 & 1.303 & 0.864 & 1.157 & 0.884 & 1.131 & 0.832 & 1.202 \\
\hline Importance of democracy & 0.961 & 1.041 & 0.939 & 1.065 & 0.815 & 1.227 & 0.675 & 1.482 & 0.916 & 1.092 & 0.785 & 1.275 \\
\hline Confidence in government & 0.966 & 1.035 & 0.934 & 1.071 & 0.825 & 1.212 & 0.905 & 1.105 & 0.889 & 1.124 & 0.865 & 1.157 \\
\hline \multicolumn{13}{|c|}{ Religiosity variables } \\
\hline Attendance at religious Services & 0.545 & 1.835 & 0.633 & 1.579 & 0.557 & 1.797 & 0.445 & $2.248 *$ & 0.744 & 1.343 & 0.636 & 1.573 \\
\hline Religious person & 0.700 & 1.428 & 0.824 & 1.214 & 0.645 & 1.551 & 0.892 & 1.120 & 0.754 & 1.327 & 0.626 & 1.597 \\
\hline Believe in god & 0.711 & 1.407 & 0.941 & 1.062 & 0.549 & 1.823 & 0.944 & 1.060 & 0.608 & 1.644 & 0.819 & 1.221 \\
\hline God importance & 0.556 & 1.799 & 0.879 & 1.137 & 0.378 & $2.645 *$ & 0.637 & 1.569 & 0.585 & 1.710 & 0.579 & 1.728 \\
\hline Praying & 0.473 & $2.116 *$ & 0.587 & 1.703 & 0.407 & $2.456 *$ & 0.432 & $2.313 *$ & 0.647 & 1.546 & 0.580 & 1.723 \\
\hline
\end{tabular}

Table 3 presents the results of logistic regression on attitudes towards accepting bribery from six different religions. The first column presented the results of explanatory variables in predicting Christian respondents' attitudes toward accepting a bribe. Sixteen variables; age, gender, education level, social class, literate situation, scale of income, sector of employment, happiness, political scale, government responsibility, importance of democracy, confidence in government, attendance at religious services, religious person, belief in God and God's importance were significantly associated with the attitudes towards accepting bribes. According to the socioeconomic variables, the elderly, females, well-educated and respondents who rated themselves as a lower social class tended to report 
stronger opposition to accepting bribes. Regarding the social bond variables respondents who were employed in government or public institutions tended to report stronger opposition to accepting bribes. In addition, higher scores in happiness, importance of democracy and left side of political scale significantly increased respondents' rejection of accepting bribes, while the lower scores in government responsibility and confidence in government increased respondents' acceptance of accepting bribes. Regarding the religiosity variables, higher scores in God's importance tended to indicate stronger opposition to accepting bribes, while the less religious people and respondents who rarely attend religious services and respondents with less belief in God were significantly less opposed to accepting bribes.

The second column presented the results of explanatory variables in predicting Muslim respondents' attitudes toward accepting bribes. Twelve variables, age, gender, scale of income, employment, sector of employment, political scale, government responsibility, importance of democracy, attendance at religious services, religious person, belief in God and God's importance were significantly associated with the attitudes towards accepting bribes. According to the socioeconomic variables, the elderly, males, well-educated and respondents who rated themselves in a lower social class tended to report stronger opposition to accepting bribes. In addition, employed people and respondents who were employed in government or public institutions were significantly associated with the attitudes towards accepting bribes. The higher score of importance of democracy and left side of political scale and the lower scores in government responsibility were significantly more opposed to accepting bribes, while the lower scores in government responsibility indicated less opposition to accepting bribes. Regarding the religiosity variables, higher scores in God's importance tended to report stronger opposition to accepting bribes, while the less religious people and respondents who rarely attend religious services were significantly less opposed to accepting bribes.

The third column presented the results of explanatory variables in predicting Hindu respondents' attitudes toward accepting bribery. Only one independent variable, religious person was significantly associated with the attitudes towards accepting bribes. Regarding this religiosity variable, the less religious people were significantly less opposed to accepting bribes.

The fourth column presented the results of explanatory variables in predicting Baha'i respondents' attitudes toward accepting bribes. Five variables, scale of income, marital status, political scale, importance of democracy and God's importance were significantly associated with the attitudes towards accepting bribes. The married, higher scores in importance of democracy, God's importance respondents' and left side of political scale tended to be more strongly opposed to accepting bribes, while respondents who rated themselves in a lower social class tended to report more acceptance of accepting bribes. 
Table 3. Logistic regression results of religions and attitudes towards accepting a Bribe.

\begin{tabular}{|c|c|c|c|c|c|c|c|c|c|c|c|c|}
\hline \multirow[b]{2}{*}{ Variables } & \multicolumn{2}{|c|}{ Christian } & \multicolumn{2}{|l|}{ Muslim } & \multicolumn{2}{|l|}{ Hindu } & \multicolumn{2}{|l|}{ Baha'i } & \multicolumn{2}{|c|}{ Buddhist } & \multicolumn{2}{|l|}{ Jew } \\
\hline & b (SE) & $\operatorname{Exp}(B)$ & b (SE) & $\operatorname{Exp}(B)$ & b (SE) & $\operatorname{Exp}(B)$ & b (SE) & Exp (B) & b (SE) & $\operatorname{Exp}(B)$ & b (SE) & $\operatorname{Exp}(\mathrm{B})$ \\
\hline \multicolumn{13}{|l|}{ Socioeconomic variables } \\
\hline Age & $0.019(0.001) * *$ & 1.019 & $0.007(0.002) * *$ & 1.007 & -- & -- & $-0.022(0.014)$ & 0.979 & $0.021(0.006)^{* *}$ & 1.021 & $0.019(0.018)$ & 1.019 \\
\hline Gender $($ Female $=1)$ & $0.081(0.034) *$ & 1.084 & $-0.197(0.060) * *$ & 0.821 & $0.165(0.468)$ & 1.180 & $-0.162(0.274)$ & 0.851 & $0.109(0.158)$ & 1.115 & $0.441(0.401)$ & 1.555 \\
\hline Education level & $0.035(0.009) * *$ & 1.036 & $0.039(0.015) *$ & 1.040 & $0.036(0.127)$ & 1.037 & $0.051(0.104)$ & 1.052 & $0.017(0.043)$ & 1.017 & $0.091(0.115)$ & 1.096 \\
\hline Social class & $0.050(0.019) * *$ & 1.052 & $-0.020(0.033)$ & 0.980 & $-0.104(0.276)$ & 0.901 & $-0.056(0.155)$ & 0.945 & $0.039(0.100)$ & 1.039 & $-0.164(0.231)$ & 0.849 \\
\hline Literate situation $($ Literate $=1)$ & $0.204(0.097) *$ & 1.226 & $-0.046(0.136)$ & 0.955 & $2.627(1.330) *$ & 13.832 & $-0.426(0.475)$ & 0.653 & $-0.009(0.640)$ & 0.991 & $-0.394(1.518)$ & 0.674 \\
\hline Scale of income & $-0.075(0.010) * *$ & 0.927 & $-0.064(0.016) * *$ & 0.938 & $-0.228(0.145)$ & 0.796 & $-0.195(0.071) * *$ & 0.823 & $-0.054(0.042)$ & 0.947 & $-0.319(0.124) * *$ & 0.727 \\
\hline \multicolumn{13}{|l|}{ Social bond variables } \\
\hline Marital status (Married $=1$ ) & $0.045(0.040)$ & 1.046 & $0.027(0.074)$ & 1.027 & $0.001(0.548)$ & 1.001 & $0.845(0.344) *$ & 2.329 & $0.197(0.203)$ & 1.218 & $0.004(0.489)$ & 1.004 \\
\hline Employment $($ Employed $=1)$ & $0.040(0.061)$ & 1.041 & $0.271(0.132)^{*}$ & 1.312 & $21.646\left(4.019 \times 10^{4}\right)$ & $2.516 \times 10^{9}$ & $-0.264(0.287)$ & 0.768 & $0.210(0.386)$ & 1.234 & $0.929(0.908)$ & 2.531 \\
\hline Sector of employment $($ Government $=1)$ & $0.150(0.040) * *$ & 1.162 & $0.215(0.065)^{* *}$ & 1.240 & $-1.100(0.623)$ & 0.333 & $-0.944(0.485)$ & 0.389 & $0.321(0.231)$ & 1.379 & $0.408(0.454)$ & 1.503 \\
\hline \multicolumn{13}{|l|}{ Attitudinal variables } \\
\hline Happiness & $0.084(0.024) * *$ & 1.087 & $0.066(0.041)$ & 1.069 & $0.209(0.369)$ & 1.233 & $0.025(0.150)$ & 1.025 & $0.159(0.131)$ & 1.173 & $-0.653(0.354)$ & 0.520 \\
\hline Political scale & $-0.037(0.008) * *$ & 0.963 & $-0.032(0.013)^{*}$ & 0.969 & $-0.053(0.112)$ & 0.948 & $-0.147(0.067) *$ & 0.863 & $-0.051(0.042)$ & 0.950 & $-0.241(0.092) * *$ & 0.786 \\
\hline Government responsibility & $-0.026(0.006) * *$ & 0.974 & $-0.038(0.010) * *$ & 0.962 & $0.124(0.094)$ & 1.133 & $-0.014(0.050)$ & 0.986 & $-0.036(0.031)$ & 0.964 & $-0.095(0.074)$ & 0.909 \\
\hline Importance of democracy & $0.171(0.008) * *$ & 1.186 & $0.102(0.014) * *$ & 1.108 & $-0.081(0.129)$ & 0.922 & $0.346(0.088) * *$ & 1.413 & $0.271(0.044) * *$ & 1.311 & $0.442(0.126)^{* *}$ & 1.556 \\
\hline Confidence in government & $-0.157(0.019) * *$ & 0.855 & $-0.033(0.030)$ & 0.968 & $0.024(0.306)$ & 1.025 & $-0.224(0.147)$ & 0.799 & $-0.115(0.105)$ & 0.891 & $-0.076(0.221)$ & 0.927 \\
\hline \multicolumn{13}{|l|}{ Religiosity variables } \\
\hline Attendance at religious services & $-0.092(0.012) * *$ & 0.912 & $-0.072(0.017) * *$ & 0.931 & $-0.219(0.152)$ & 0.803 & -- & -- & $0.040(0.053)$ & 1.041 & $0.019(0.123)$ & 1.019 \\
\hline Religious person (Religious person $=1$ ) & $-0.124(0.050) *$ & 0.884 & $-0.540(0.078) * *$ & 0.583 & $-1.309(0.575) *$ & 0.270 & $0.783(0.780)$ & 2.188 & $-0.276(0.177)$ & 0.759 & $0.906(0.452) *$ & 2.475 \\
\hline Believe in God (Yes $=1)$ & $-0.167(0.081) *$ & 0.847 & $-0.006(0.260)$ & 0.994 & $-2.591(1.527)$ & 0.075 & $18.852(2.273 \mathrm{E} 4)$ & 1.540 & $-0.123(0.249)$ & 0.885 & $-1.563(0.996)$ & 0.210 \\
\hline God importance & $0.075(0.009) * *$ & 1.078 & $0.239(0.016) * *$ & 1.270 & -- & -- & $0.263(0.092) * *$ & 1.300 & $0.000(0.040)$ & 0.999 & $-0.054(0.103)$ & 0.947 \\
\hline Praying & -- & -- & $0.012(0.015)$ & 1.012 & -- & -- & -- & -- & $-0.028(0.046)$ & 0.972 & $0.008(0.112)$ & 1.008 \\
\hline $\mathrm{R}^{2}$ (Nagelkerke) & 0.079 & & 0.082 & & 0.273 & & 0.248 & & 0.102 & & 0.247 & \\
\hline $\mathrm{R}^{2}$ (Cox and Snell) & 0.108 & & 0.117 & & 0.317 & & 0.344 & & 0.147 & & 0.342 & \\
\hline
\end{tabular}

$* p<0.05 ; * * p<0.01 ;--$ Exclusion of highly correlated independent variables. 
The fifth column presented the results of explanatory variables in predicting Buddhist respondents' attitudes toward accepting bribes. Two variables, age and importance of democracy were significantly associated with the attitudes towards accepting bribes. The elderly and those who had strong support for democracy tended to be more strongly opposed to accepting bribes, while none of the other variables were statistically significant.

The final column presented the results of explanatory variables in predicting Jewish respondents' attitudes toward accepting bribes. Four variables, scale of income, political scale, importance of democracy and religious person were significantly associated with the attitudes towards accepting bribes. Higher scores in importance of democracy, left side of political scale, lower social class and more religious people tended to be more strongly opposed to accepting bribes, while none of the other variables were statistically significant.

\section{Conclusions}

Table 4 shows which variables had significant differences. The Christian category had the most significant differences (16), followed by the Muslim category (12). The differences were significant for Hindus and Buddhists in only two cases.

Table 4. Summary of significant difference.

\begin{tabular}{|c|c|c|c|c|c|c|}
\hline & Christian & Muslim & Hindu & Baha'i & Buddhist & Jew \\
\hline \multicolumn{7}{|c|}{ Socioeconomic variables } \\
\hline Age & $\mathrm{X}$ & $\mathrm{X}$ & & & $\mathrm{X}$ & \\
\hline Gender & $\mathrm{X}$ & $\mathrm{X}$ & & & & \\
\hline Education level & $X$ & $X$ & & & & \\
\hline Social class & $\mathrm{X}$ & & & & & \\
\hline Literate situation & $\mathrm{X}$ & & $X$ & & & \\
\hline Scale of income & $\mathrm{X}$ & $\mathrm{X}$ & & $X$ & & $X$ \\
\hline \multicolumn{7}{|c|}{ Social bond variables } \\
\hline Marital status & & & & $X$ & & \\
\hline Employment & & $\mathrm{X}$ & & & & \\
\hline Sector of employment & $X$ & $\mathrm{X}$ & & & & \\
\hline \multicolumn{7}{|c|}{ Attitudinal variables } \\
\hline Happiness & $\mathrm{X}$ & & & & & \\
\hline Political scale & $X$ & $X$ & & $\mathrm{X}$ & & $\mathrm{X}$ \\
\hline Government responsibility & $\mathrm{X}$ & $\mathrm{X}$ & & & & \\
\hline Importance of democracy & $\mathrm{X}$ & $\mathrm{X}$ & & $X$ & $X$ & $X$ \\
\hline Confidence in government & $\mathrm{X}$ & & & & & \\
\hline \multicolumn{7}{|c|}{ Religiosity variables } \\
\hline Attendance at religious Services & $\mathrm{X}$ & $\mathrm{X}$ & & & & \\
\hline Religious person & $\mathrm{X}$ & $\mathrm{X}$ & $X$ & & & $X$ \\
\hline Believe in god & $X$ & & & & & \\
\hline God importance & $X$ & $\mathrm{X}$ & & $\mathrm{X}$ & & \\
\hline Praying & & & & & & \\
\hline
\end{tabular}


As was pointed out earlier, a large percentage of the sample population believed that accepting a bribe was never justifiable. However, many participants in this study believed that accepting a bribe was acceptable in certain situations.

Although the present study found that there was widespread opposition to accepting a bribe, at least in most cases, and that religion and certain demographic variables often played a role in determining the extent of opposition, more research could be done on this topic. Those collecting the survey data did not ask respondents the reason for their opinion. Asking for the reason for their position would have yielded additional valuable information. However, it is understandable that the WVS people would not ask this question, since doing so would have made the collection of data overly burdensome, given the fact that the bribery question was only one of several hundred questions that were included in the survey instrument.

It would be interesting to know why certain variables, such as religion, degree of religiosity, age, gender, education level, and so forth, sometimes made a difference. More research could be conducted on each of the demographic variables included in the present study.

The present study lumped together the various subsets of the six religious groups. Further research could be conducted to disaggregate these groups. For example, the Christian group lumped together the Catholic and various Protestant denominations, and the Muslim group lumped the Sunni and Shia groups together. It would be interesting to see whether the various divisions within these subgroups held differing views on the ethics of accepting a bribe, and whether the Catholics in North America might hold views that are different from the views of Catholics in Europe, for example. Some studies have been conducted that examine the differences between the various religious subgroups on the question of tax evasion ethics, but no such study has been done on the issue of bribery ethics to date [33].

The survey instrument used in the present study asked whether it would be ethically acceptable to take a bribe, but not whether it would be ethical to offer a bribe. The ethics of the situation might also depend on whether the bribe is solicited or not. For example, would it be ethical to pay a bribe that has been solicited, but unethical to offer to pay a bribe? These are separate ethical questions, and one may not assume that the responses to these two situations would be the same. Studies that would compare the results of these two different fact situations would be informative.

The present study merely asked whether accepting a bribe would be justifiable. It did not mention whether the bribe was of the helping hand or greedy hand variety. Would the views on bribery differ, depending on whether the person who took the money did something to help the other party, such as circumventing red tape or excessively burdensome regulations? Some studies on this aspect of the topic would be informative.

\section{Author Contributions}

Serkan Benk and Bahadır Yüzbaşı designed the study and conducted statistical analysis. Robert W. McGee and Serkan Benk contributed to the analysis and writing.

\section{Conflicts of Interest}

The authors declare no conflict of interest. 


\section{References}

1. Bruce D. Jhonsen. "The ethics of commercial bribery: Integrative social contract theory meets transaction cost economics.” Journal of Business Ethics 88 (2009): 791-803.

2. Daniel Kaufmann, and Shang-Jin Wei. Does "Grease Money" Speed Up the Wheels of Commerce? Washington: National bureau of economic research, 1999.

3. Robert E. Goodin. Utilitarianism as a Public Philosophy. Cambridge: Cambridge University Press, 1995.

4. Richard B. Brandt. Morality, Utilitarianism, and Rights. Victoria: Cambridge University Press, 1992.

5. Raymond Gillespie Frey, ed. Utility and Rights. Minneapolis: University of Minnesota Press, 1984.

6. Immanuel Kant. Fundamental Principles of the Metaphysics of Morals. New York: Courier Corporation, 2012.

7. Aristotle. Nichomachean Ethics. Oxford: Oxford University Press, 2002.

8. Marcia Baron, Philip Pettit, and Michael Slote. Three Methods of Ethics. Malden and Oxford: Blackwell Publishing, 1997.

9. Gibson Graham. Eight Methods of Ethics. London and New York: Routledge, 2004.

10. Alan Wong, and Eugene Beckman. "An applied ethical analysis system in business." Journal of Business Ethics 11 (1992): 173-78.

11. Bill Shaw. "Foreign corrupt practices act: A legal and moral analysis." Journal of Business Ethics 7 (1988): 789-95.

12. Peter Egger, and Hannes Winner. "Evidence on corruption as an incentive for foreign direct investment." European Journal of Political Economy 21 (2005): 932-52.

13. Alvaro Cuervo-Cazurra. "The effectiveness of laws against bribery abroad." Journal of International Business Studies 39 (2008): 634-51.

14. Paolo Mauro. "Corruption and growth.” The Quarterly Journal of Economics 110 (1995): 681-712.

15. Enrico Colombatto. "Why is corruption tolerated?" The Review of Austrian Economics 16 (2003): 363-79.

16. Rajib Sanyal, and Subarna Samanta. "Relationship between Bribery and Economic Growth: An Empirical Analysis." Indian Journal of Economics \& Business 9 (2010): 133-45.

17. Shane R. Premeaux, and R. Wayne Mondy. "Linking management behavior to ethical philosophy." Journal of Business Ethics 12 (1993): 349-57.

18. Shane R. Premeaux. "The current link between management behavior and ethical philosophy." Journal of Business Ethics 51 (2004): 269-78.

19. Anand Swamy, Stephen Knack, Young Lee, and Omar Azfar. "Gender and corruption." Journal of Development Economics 64 (2001): 25-55.

20. Achinto Roy, and Alan E. Singer. "Reducing corruption in international business: Behavioural, managerial and political approaches." Journal of Economic and Social Policy 10 (2006): 1-18.

21. Pavel Dimitrov Atanasov. "Bribery as Negotiation: A Decision Making Perspective." Paper presented at IACM 24TH Annual Conference, New York, NY, USA, 3-6 July 2011.

22. Organization for Economic Co-operation and Development (OECD). Convention on Combating Bribery of Foreign Public Officials in International Business Transactions and Related Documents. Paris: OECD, 2011. 
23. Nicola Bonucci, and Patrick Moulette. "The OECD Anti-Bribery Convention 10 years on." The OECD Observer, 2007. Available online: http://www.oecdobserver.org/news/archivestory. php/aid/2475/The_OECD_AntiBribery_Convention_10_years_on.html (accessed on 10 April 2015).

24. Masako N. Darrough. "The FCPA and the OECD convention: Some lessons from the US experience." Journal of Business Ethics 93 (2010): 255-76.

25. Juan I. Sanchez, Carolina Gomez, and Guillermo Wated. "A value-based framework for understanding managerial tolerance of bribery in Latin America." Journal of Business Ethics 83 (2008): 341-52.

26. Richard A. Bernardi, Michael B. Witek, and Michael R. Melton. "A four-country study of the associations between bribery and unethical actions." Journal of Business Ethics 84 (2009): 389-403.

27. World Values Survey. "World Values Survey wave 6 (2010-2012)." Available online: http://www.worldvaluessurvey.org/WVSDocumentationWV6.jsp (accessed on 23 April 2015).

28. Teresa Hernandez, and Robert W. McGee. "The Ethics of Accepting a Bribe: An Empirical Study of Opinion in the USA, Brazil, Germany and China." International Journal of Business, Accounting, and Finance 6 (2012): 178-96.

29. Teresa Hernandez, and Robert W. McGee. "Ethical Attitudes toward Taking a Bribe: A Study of Three Latin American Countries." International Journal of Business \& Economics Perspectives 8 (2013): 142-66.

30. David W. Hosmer, and Stanley Lemeshow. Applied Regression Analysis. New York: John Willey, 1989.

31. Scott Menard. Applied Logistic Regression Analysis. Thousand Oaks: SAGE Publication, 1995.

32. Paul D Allison. Logistic Regression Using SAS: Theory and Application. Cary: SAS Institute, 2012.

33. Robert W. McGee, ed. The Ethics of Tax Evasion: Perspectives in Theory and Practice. North Miami: Springer, 2012.

(C) 2015 by the authors; licensee MDPI, Basel, Switzerland. This article is an open access article distributed under the terms and conditions of the Creative Commons Attribution license (http://creativecommons.org/licenses/by/4.0/). 